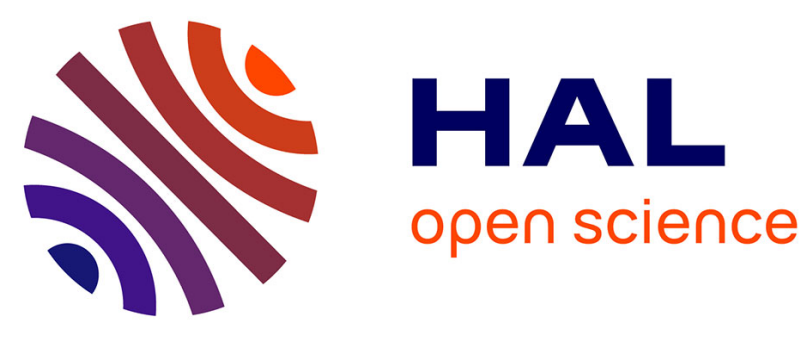

\title{
Solid oxide fuel cell fault diagnosis and ageing estimation based on wavelet transform approach
}

Elodie Pahon, Nadia Steiner, Samir Jemei, Daniel Hissel, Marie-Cécile Péra, Kun Wang, Philippe Moçoteguy

\section{- To cite this version:}

Elodie Pahon, Nadia Steiner, Samir Jemei, Daniel Hissel, Marie-Cécile Péra, et al.. Solid oxide fuel cell fault diagnosis and ageing estimation based on wavelet transform approach. International Journal of Hydrogen Energy, 2016, 41 (31), pp.13678-13687. 10.1016/j.ijhydene.2016.06.143 • hal-02130963

\section{HAL Id: hal-02130963 \\ https://hal.science/hal-02130963}

Submitted on 21 Oct 2021

HAL is a multi-disciplinary open access archive for the deposit and dissemination of scientific research documents, whether they are published or not. The documents may come from teaching and research institutions in France or abroad, or from public or private research centers.
L'archive ouverte pluridisciplinaire HAL, est destinée au dépôt et à la diffusion de documents scientifiques de niveau recherche, publiés ou non, émanant des établissements d'enseignement et de recherche français ou étrangers, des laboratoires publics ou privés. 


\title{
Solid oxide fuel cell fault diagnosis and ageing estimation based on wavelet transform approach
}

\author{
E. Pahon ${ }^{\text {a, }}$, N. Yousfi Steiner ${ }^{\text {a,b }}$, S. J emei ${ }^{\text {a }}$, D Hssel ${ }^{\text {a }}$, M.C. Péra ${ }^{\text {a }}$, \\ K. Wang ${ }^{\text {a }}$, P. Moçoteguy ${ }^{c}$ \\ ${ }^{a}$ FEMTO-ST UMR CNRS 6174, FCLAB Research Federation FR CNRS 3539, University Bourgogne Franche-Comte, rue \\ Ernest Thierry Mieg, 90010 Belfort Cedex, France \\ ${ }^{\mathrm{b}}$ LABEX ACTION CNRS, FEMTO-ST UMR CNRS 6174, FCLAB Research Federation FR CNRS 3539, University \\ Bourgogne Franche-Comte, rue Ernest Thierry Mieg, 90010 Belfort Cedex, France \\ ${ }^{c}$ EIFER, European Institute for Energy Research, Emmy-Nother Strasse 11, 76131 Karlsruhe, Germany
}

\begin{abstract}
The paper aims at developing a signal-based diagnosis tool diagnosing a high temperature fuel cell named solid oxide fuel cell (SOFC). The wavelet transform (WT) has been used to decompose the SOFCs voltage signals and to find out the effective feature variables that are discriminative for distinguishing the normal and abnormal operating conditions of the system. The diagnosis method is used to detect and isolate SOFC system fault by using the fuel cell stack as a sensor. Considering this, on-line fault detection without any additional sensor is available.
\end{abstract}

\section{Introduction}

Nowadays, the hydrogen encountered a great interest as a fuel, and more efforts are done by industry and governmental institutions to develop hydrogen-based devices [1,2]. Hydrogen is the most abounding chemical element in the universe. On Earth, hydrogen does not exist in a natural state but is very plentiful in the form of atom. This atom has to be extracted from his combination with other atoms (like in water: $\mathrm{H}_{2} \mathrm{O}$ ) by the mobilization of a source of energy. Nevertheless, the International Energy Agency underlines in Ref. [3] that the main hydrogen source is hydrocarbon reforming [4], even if it can be obtained through green energy procedures. Solid oxide fuel cells (SOFC) [5-9] represent an emerging technology for clean, reliable, and flexible power production [10]. High temperature fuel cells convert chemical energy of fossil fuel into electrical energy [11]. Thus, they are highly efficient and imply low carbon dioxide emission energy conversion devices [12-14]. Compared to other fuel cell

* Corresponding author. Tel.: +33 384583 628; fax: +33 384583636.

E-mail addresses: elodie.pahon@univ-fcomte.fr (E. Pahon), nadia.steiner@eifer.org (N. Yousfi Steiner), samir.jemei@univ-fcomte.fr (S. Jemei), daniel.hissel@univ-fcomte.fr (D. Hissel), marie-cecile.pera@univ-fcomte.fr (M.C. P'era), kun.wang@univ-fcomte.fr (K. Wang), philippe.mocoteguy@eifer.org (P.Mocsoteguy). 
technologies, the main advantages of the SOFCs are the wide range of applications and the flexibility of fuel tolerated $[15,16]$, also when pure hydrogen derived from renewable energies is used, there is no pollution of environment $[17,18]$. In Ref. [19], another effective solution to environmental and efficiency issues are to couple the SOFC with a conventional gas turbine: this hybrid system allows reducing pollutants emissions [20] and allows cogeneration applications by exhausting gases at desired temperature [21,22]. Nevertheless, the big issue is that SOFCs have not reached commercialization yet and are still an expensive technology. Moreover, theoretically, fuel cells should produce electrical energy as long as they are fed with gases. Unfortunately, it is not the case because of potential failures on the system, and intensive research studies about diagnosis method in order to increase the lifetime by limiting the performance degradation are being conducted. In Ref. [23], Tu et al. present some ageing mechanisms and lifetime in solid oxide fuel cells. They identify some kinetics and operating conditions that contribute to address lifetime limitation. Thus, the field of system diagnosis is more studied. Diagnosis tools are essential to avoid premature degradation of the fuel cell. The main task of fault diagnosis is to evaluate the deviation of the current state from the normal behaviour of the fuel cell, by detecting the hazardous states. The SoH has to be identified by diagnosing these faulty modes. To reach this goal, several stages have to be followed as: data acquisition, data treatment and fault detection. Firstly, datasets must be collected from the system, operated under different operating modes (healthy and faulty modes). Data treatment aims at extracting and selecting features that enable characterizing the behaviour of the FC [24]. Two main approaches of fault diagnosis have been developed: modelbased method [25-27] and signal-based approach [28-30]. A review on diagnosis methodology and technique for SOFC is given in Ref. [31]. Two reviews on modelling listed the different fault detection methods: Andersson et al. [32] present the modelling development for multiscale chemical reactions coupled transport phenomena in SOFC whereas Zabihian et al. [33] review the modelling of hybrid SOFC systems. In Ref. [34], a method is developed in order to estimate dynamically the temperature inside the $10 \mathrm{~kW}$-SOFC by using a data-based modelling. For the model-based approach, a large amount of data is required in order to increase the precision of the diagnosis. In Refs. [35,36], the wavelet-based method is used for on-board energy management for a hybrid vehicle. In these works, the diagnosis method consists in implementing sensors in a system in order to detect parameters deviations from nominal operating conditions. As the fuel cell system complexity increases, another way to achieve diagnosis is to analyze and use the system responses to a solicitation signal as a state of health $(\mathrm{SoH})$ indicator, with the aim to use only already available measurements on the system. The signal-based method using wavelet transform allows reducing the requirement of experimental data which induced saving time and money. Diagnosis procedure will be therefore carried out using either the stack or the complete system as its own sensor [37]. A focus is done on the stack voltage signal. The stack voltage is analyzed with the chosen diagnosis tool (i.e. WT). Without database and relevant information about the faulty and healthy modes and knowledge about the FC system behaviours, fault diagnosis cannot be achieved. In this paper, a signal-based approach is chosen. The WT is a method for signal decomposition but it is not sufficient to diagnose the fuel cell system state. Regardless of the approach, the aim is to generate indicators that distinguish the normal and abnormal SoH. Three indicators extracted from the fuel cell signal are exposed. They allow performing a fast fault diagnosis result as patented in Ref. [38]. Thus, the WT approach is coupled with the analysis of some indicators like the wavelet energy and the wavelet entropy, which gives interesting results. The stack experiments including two different short stacks are described in the third section. The datasets obtained are used to provide some results for fault diagnosis and also for the estimation of the state of health of the fuel cell while performing long-term test. The fault diagnosis algorithm performances are given in the last part of the paper according to the indicator (energy of entropy) and also depending on the stack studied.

\section{Signal-based method}

The method is based on the wavelet transform (WT) of the stack voltage signals extracted from different kinds of tests coming from two different SOFCs (presented on the following Section Application to fuel cell). The WT is one of the most popular candidates of the time-frequency transformations [39-42] (that implies extracting time and frequency information from the input signal studied). The continuous WT is defined by Eq. (1).

$C(u, s)=\frac{1}{\sqrt{s}} \int f(t) \cdot \Psi *\left(\frac{t-u}{s}\right) d t$

where $f(t)$ is the original signal, $C(u, s)$ is the transformed signal, $u$ is the translation parameter and $s$ the scale parameter. The translation parameter corresponds to the time information in the transformed domain whereas the scale parameter is proportional to $1 /$ signal $_{\text {frequency }}$. A larger scale denotes a dilated wavelet and a smaller scale denotes a compressed wavelet as presented in Fig. 1.

The WT acts like a filter which splits the high frequency and the low frequency contents. The filtering process is given on Fig. 2. The input signal is downsampled and results in two subsignals. The approximation subsignal denotes the low frequency or high scale of the input signal whereas the high frequency is illustrated by the detail or small scale of the input signal. In the case of multi-level decomposition of the initial signal $f$, the behaviour described on Fig. 2 is repeated. The approximation is successively decomposed in two subsignals: one detail and one approximation. According to the principle

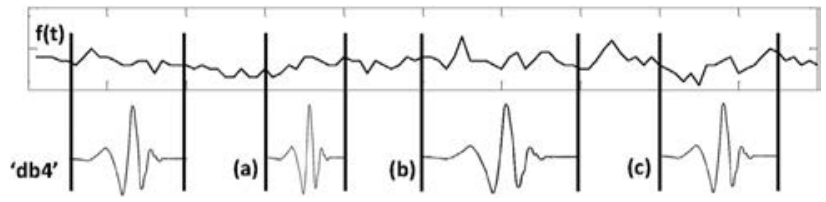

Fig. 1 - (a) Compressed scale, (b) Dilated scale, (c) Translation of the initial Daubechies wavelet called "db4". 


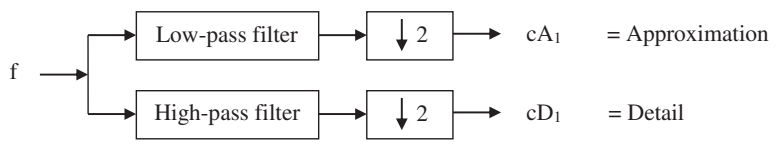

Fig. 2 - One-step wavelet filtering.

of discrete wavelet transform, $j$-levels decomposition gives $j$ approximation components and $j$ detail components of the signal $f$. Each of these components is composed of a vector of wavelet coefficients, denoted $\mathrm{cA}_{j}$ (for the approximation component) or $\mathrm{CD}_{j}$ (for the detail component) and is related to a specific frequency band [43] (c.f. Fig. 3). At each level of decomposition $j$, the sampling frequency $f_{s}$ is halved.

As an example, a steady stack voltage signal, with a sampling frequency $f_{s}$, is decomposed with five levels (c.f. Fig. 4). Fig. 5 illustrates the behaviour of the SOFC stack voltage by giving the last approximation signal $\mathrm{CA}_{5}$ and all the $j$ details $c D_{j}$.

\section{Wavelet energy and its normalization}

In the time domain, the energy of a signal is the sum of the squares of its time-series values. Similarly, the energy of a subsignal obtained from discrete WT is the sum of squares of its wavelet coefficients [43]. The wavelet energy is indicated by:

$E_{j}^{d}=\sum_{k}\left|C_{j}^{d}(k)\right|^{2}$

$E_{\text {tot }}^{d}=\sum_{j} \sum_{k}\left|C_{j}^{d}(k)\right|^{2}=\sum_{j} E_{j}^{d}$

where $j$ is the level of decomposition of the WT and $d$ represents a detail subsignal.

Thus, a value of $E_{j}^{d}$ is obtained for each detail $d$ at each level of decomposition $j$. Finally, the global sum of all $E_{j}^{d}$ gives the total wavelet energy (TWE) contained in the initial signal. The normalization of the wavelet energy $p_{j}^{d}$, named relative wavelet energy, is calculated as:

$p_{j}^{d}=\frac{E_{j}^{d}}{E_{\text {tot }}^{d}}$

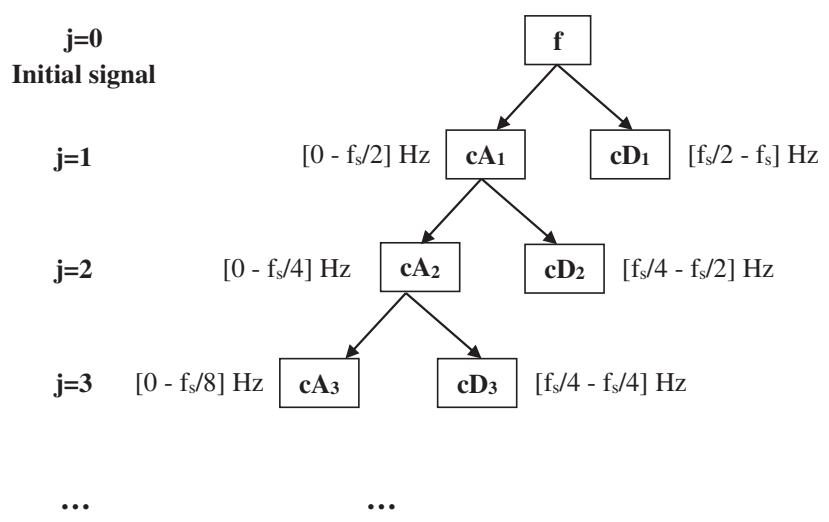

Fig. 3 - Discrete wavelet decomposition tree. where $j$ is the level of decomposition and $d$ the detail subsignal. This representation allows a better visualisation of the energy distribution of the initial signal over all the frequency bands, whereas the TWE measures the fluctuation rate at a relevant frequency band determined by the decomposition level $j$.

\section{Total wavelet entropy and its normalization}

Another indicator called the entropy is very useful for measuring the amount of information contained in a signal and especially its regularity (the bigger is the entropy value, the less regular is the signal). Eq. (5) gives the formula of the total wavelet entropy (TWP), expressed by $S_{W T}$. When the value of the TWP reaches a high value, it means that the degree of disorder of the energy distribution in the detail signal is high.

$\mathrm{S}_{\mathrm{WT}}=-\sum_{j} p_{j}^{d} * \ln \left(p_{j}^{d}\right)$

where $j$ is the level of decomposition and $d$ the detail subsignal. In the same way as for the wavelet energy, the TWP can be normalized as expressed in Eq. (6). The relative wavelet entropy (RWP), denoted by $q_{j}^{d}$, measures the resemblance between two different signals in terms of energy content. It is expressed as the summation of wavelet coefficients within a selected frequency range over time [44].

$\left.\mathrm{S}_{\mathrm{WT}}(p \mid q)=\sum_{j} p_{j}^{d} * \ln \frac{p_{j}^{d}}{q_{j}^{d}}\right)$

where $j$ is the level of decomposition and $d$ the detail subsignal.

\section{Application to fuel cell}

The signal-based method described above is applied on two different SOFC stacks with respectively 3 and 6 cells, operated under nominal and non-nominal conditions. Thus, two datasets are available to perform the diagnosis based on the wavelet energy and entropy approaches. The general process followed in this work is described in Fig. 6: first, two sets of data are monitored on the two different SOFC stacks. The diagnosis algorithm that consists in a wavelet transformation of the cells and stack voltages, followed by an energy-based and an entropy-based indicators extraction is applied (Fig. 7).

\section{6-cell SOFC stack}

A test is performed on a SOFC system equipped with a 6-cell planar SOFC stack. A specific oven has to keep the stack at given requested temperature. Further information is presented in Table 1.

The tests are carried out according to the design of experiments (DoE) methodology [45]. 16 tests are proposed corresponding to 16 different operating conditions symmetrically around a nominal operating point (considered as the healthy condition and the reference). The effect of both fuel and air utilization (respectively FU and AU), current density (J) and 


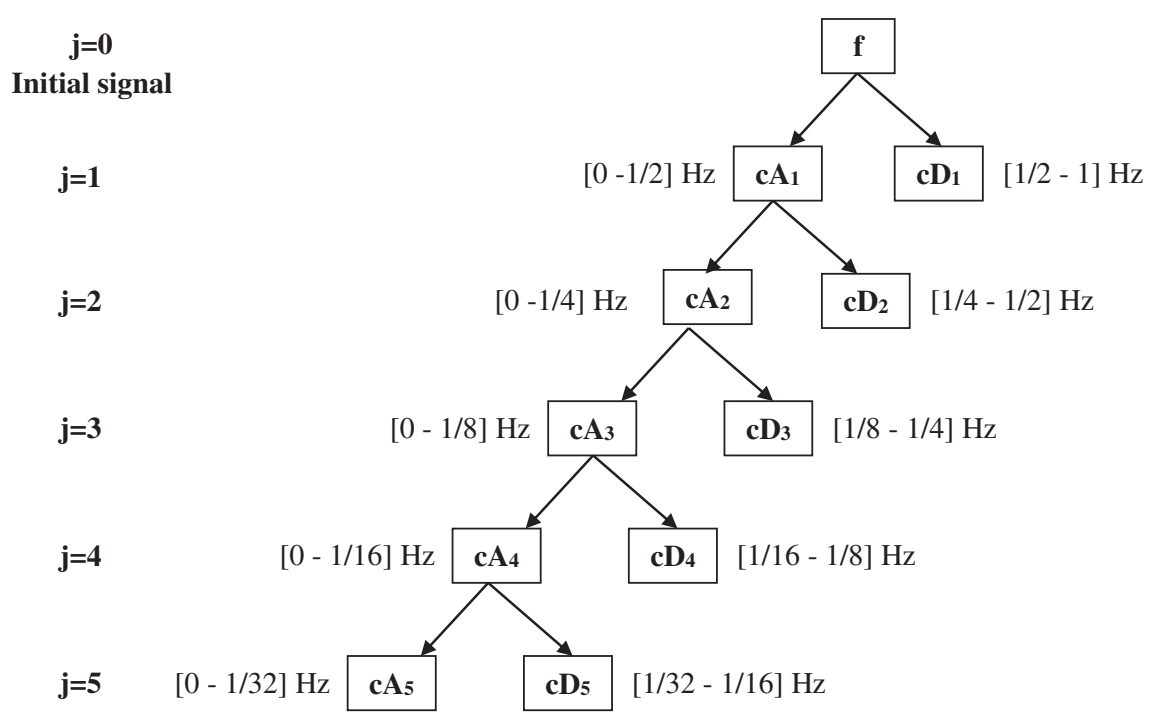

Fig. 4 - 5-level decomposition of the SOFC voltage signal.

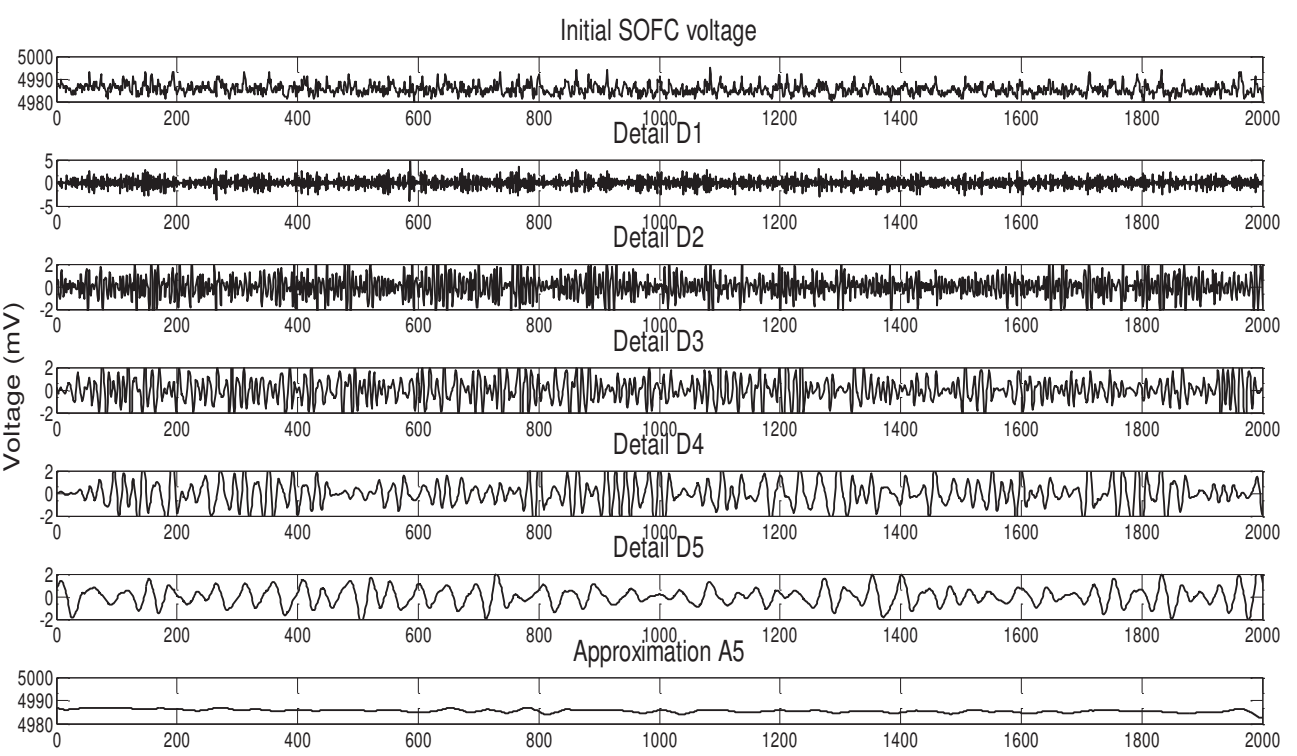

Fig. 5 - An example of a 5-level discrete db4 WT on an SOFC voltage signal.

temperature $(\mathrm{T})$ is grouped in Table 2 . These 16 cases define a bounded area for which the stack is allowed to work safely. The single cells voltage signals are all measured at the steady state with a stabilization phase from 3 to $5 \mathrm{~h}$ between each experiment, in order to reach stabilized operating conditions. The variations of the operating conditions are made slowly and step-by-step when changing operating mode, in order to avoid fuel cell stack damages.

The experiments were carried out in series, operating the stack continuously in the following order $[0 ; 1 ; 2 ; 4 ; 3 ; 0 ; 7 ; 8 ; 6$; $5 ; 0 ; 9 ; 10 ; 12 ; 11 ; 0 ; 15 ; 16 ; 14 ; 13 ; 0]$. A stabilization perdio of $3-5 \mathrm{~h}$ at each of the operating conditions was allowed before changing to the next condition. All transitions between operating points were done gradually, by "small" step-wise changes. The stack was galvanostatically controlled so the average current density was set directly. Similarly, the stack FU and fuel humidity were also set directly by adjusting the fuel components mass flow accordingly. The furnace temperature refers to the set-point for the furnace temperature controller. All measurements were recorded with a $1 \mathrm{~Hz}$ frequency.

\section{3-cell SOFC stack}

The test done on this fuel cell allows collecting voltage signals measured at different time under steady state conditions as shown in Fig. 8. The fuel cell progressively degraded with the progression of the test and therefore allows the validation of the algorithm on ageing. The stack is fed by a mix of gas, emulating the outlet of a reformer. The FU is given by the hydrogen fuel utilization. Fig. 8 illustrates the behaviour of the SOFC depending on the lifetime. The global test is performed during $1677 \mathrm{~h}$ of functioning with a furnace temperature of $770{ }^{\circ} \mathrm{C}$. Table 3 gives the nominal operating conditions. A 


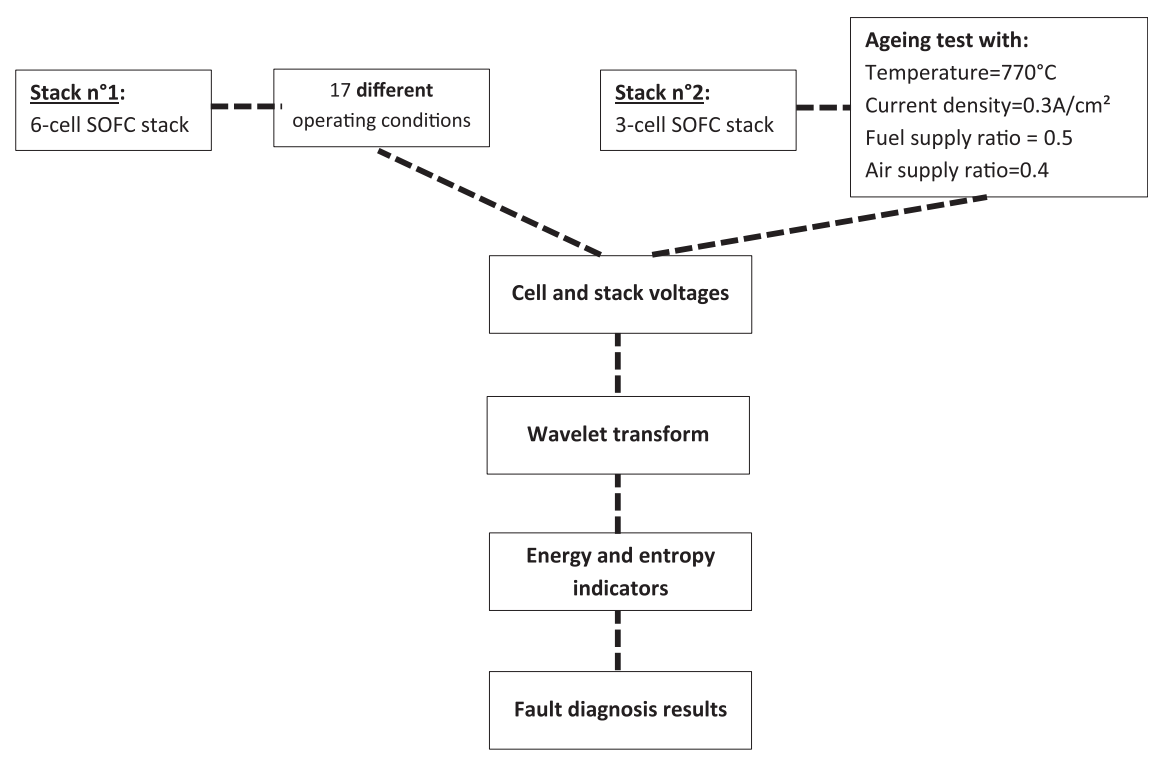

Fig. 6 - Global fault diagnosis procedure.

Stack voltage $(\mathrm{mV})$

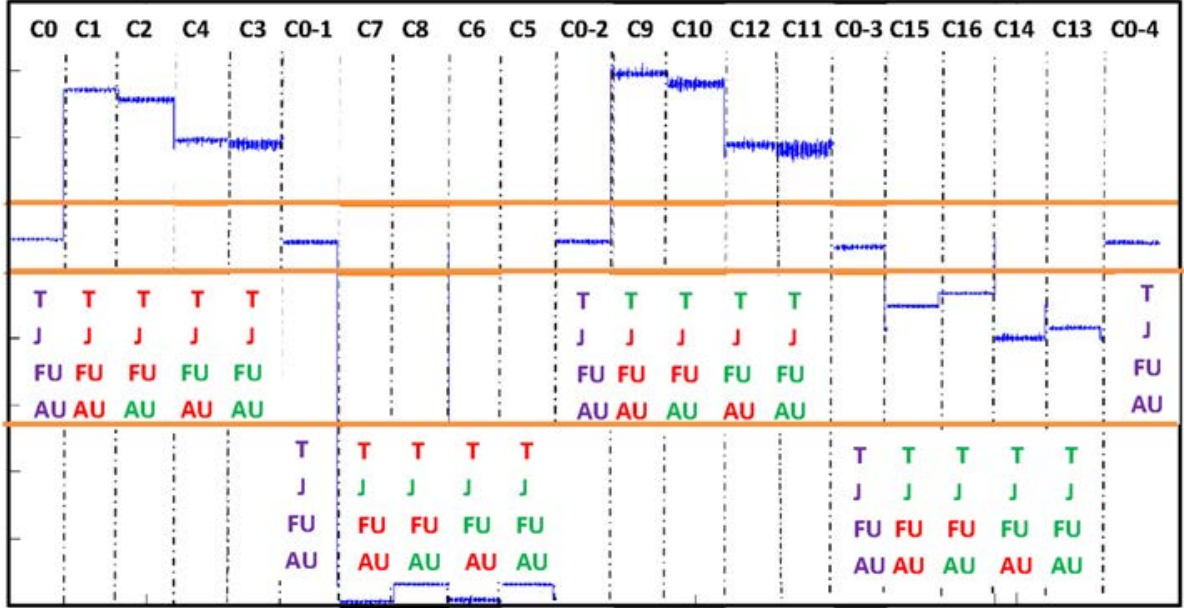

Fig. 7 - SOFC steady state voltages depending on the 16 operating conditions.

polarization curve is done, every $100 \mathrm{~h}$, in order to check the degradation of the stack. The polarization resistance is calculated in the linear area of the I-V curve at about $10 \mathrm{~A}$. That gives $50.8 \mathrm{~m} \Omega$ at the beginning of the test $(20 \mathrm{~h}$ of functioning) and reaches $53.4 \mathrm{~m} \Omega$ after 1121 operating hours. The

Table 1 - 6-cell stack specifications.

Parameter

Value

Number of cells

Fuel (mol\%)

Active area per cell

Nominal temperature

Nominal current density

Nominal fuel utilization (FU)

\section{6}

$\mathrm{H}_{2}(21)-\mathrm{N}_{2}(67)-\mathrm{H}_{2} \mathrm{O}(12)$

$50 \mathrm{~cm}^{2}$

$760{ }^{\circ} \mathrm{C}$

$0.3 \mathrm{~A} / \mathrm{cm}^{2}$

0.5

Nominal air utilization (AU) polarization resistance increases by $5 \%$ in $1100 \mathrm{~h}$. The stack voltage degradation at a current of $10 \mathrm{~A}$ is evaluated at $92 \mu \mathrm{V}$ per operating hour or about $30 \mu \mathrm{V}$ per cell and per operating hour. The sampling frequency is $3 \mathrm{~Hz}$.

\section{Results}

The fault diagnosis process of the both SOFC stacks is described in Fig. 6 (Section Application to fuel cell). A specific wavelet is used for the transformation, namely the Daubechies wavelet. One of its main advantage is that the $d b 4 \mathrm{WT}$ can redistribute the energy of a signal and compress most of energy in the final obtained approximation subsignal [40]. Once the wavelet family chosen, a 5-level decomposition range is used based on the related frequency bands. As 
Table 2 - The 16 operating conditions tested.

\begin{tabular}{lcccc}
$\begin{array}{l}\text { Experiment } \\
\text { number }\end{array}$ & $\begin{array}{c}\text { Temperature } \\
\left({ }^{\circ} \mathrm{C}\right)\end{array}$ & $\begin{array}{c}\text { Current } \\
\text { density } \\
\left(\mathrm{A} / \mathrm{cm}^{2}\right)\end{array}$ & $\begin{array}{c}\text { Fuel } \\
\text { utilization } \\
\text { ratio }\end{array}$ & $\begin{array}{c}\text { Air } \\
\text { utilization } \\
\text { ratio }\end{array}$ \\
\hline 0 & 760 & 0.3 & 0.5 & 0.4 \\
1 & 700 & 0.1 & 0.4 & 0.3 \\
2 & 700 & 0.1 & 0.4 & 0.5 \\
3 & 700 & 0.1 & 0.6 & 0.3 \\
4 & 700 & 0.1 & 0.6 & 0.5 \\
5 & 700 & 0.5 & 0.4 & 0.3 \\
6 & 700 & 0.5 & 0.4 & 0.5 \\
7 & 700 & 0.5 & 0.6 & 0.3 \\
8 & 700 & 0.5 & 0.6 & 0.5 \\
9 & 820 & 0.1 & 0.4 & 0.3 \\
10 & 820 & 0.1 & 0.4 & 0.5 \\
11 & 820 & 0.1 & 0.6 & 0.3 \\
12 & 820 & 0.1 & 0.6 & 0.5 \\
13 & 820 & 0.5 & 0.4 & 0.3 \\
14 & 820 & 0.5 & 0.4 & 0.5 \\
15 & 820 & 0.5 & 0.6 & 0.3 \\
16 & 820 & 0.5 & 0.6 & 0.5 \\
\hline & & & & \\
\hline
\end{tabular}

presented all along the paper, the diagnosis indicators are the energy and the entropy of the given signal. These parameters (energy and entropy) are calculated depending on the different operating conditions and on the number of cells in the stack. First, the RWE of each five details of the initial signal is extracted and analyzed. Afterwards, some TWP and RWP results are exposed in order to determine the abnormal and potentially degrading operating conditions for the SOFC.

\section{6-cell diagnosis results}

\section{a. The RWE indicators}

Fig. 9 shows the high frequency part of the SOFC voltage signal represented by five details $D_{1}$ to $D_{5}$. The energy content of each indicator of the high frequency filtering is plotted versus the individual cell number, linked to the 16 abnormal states and the nominal modes. 20 graphs are shown and give a large database in order to observe and to extract a specific behaviour of the RWE of the details. By analysing Fig. 9, the first row considers the same operating conditions in terms of current density, fuel utilization and air utilization, as the third row but at two levels of temperature $\left(700^{\circ} \mathrm{C}\right.$ and $\left.820^{\circ} \mathrm{C}\right)$. The second column considers the same operating conditions in terms of current density, fuel utilization and air utilization as the fourth row but at the same two levels of temperature $\left(700{ }^{\circ} \mathrm{C}\right.$ and $\left.820^{\circ} \mathrm{C}\right)$. The last row describes the energy distribution of the high frequency part of the voltage signal at nominal operating conditions. The energy of the detail $D_{1}$ is the most important and is about 0.5 . That means a half $(50 \%)$ of fluctuation energy is contained in the 1st level detail subsignal which is related to the frequency interval of $[0.5,1] \mathrm{Hz}$ [43]. The energy repartition is spread as follows: $D_{1}$ (the most energetic) $-D_{2}-D_{3}-D_{4}-D_{5}$ (the less energetic). Thus, all the conditions which give more or less the same distribution is associated to normal operating conditions and the other are considered as faulty states.
Four faulty conditions are underlined: C4 - C10 - C11 - C12 and are recalled in Table 4, in order to see the variations of the four parameters according to the nominal mode. Several observations are made:

- They are all at a lower current density than expected for the stack;

- Three of them have a higher temperature than the nominal conditions (C10 - C11 - C12);

- Three of them have a higher fuel utilization than the nominal conditions (C4 - C11 - C12);

- Three of them have a higher air utilization than the nominal conditions (C4 - C10 - C12);

- All the faulty conditions have approximately the same distribution which is not well separated;

- The energetic content of the details does not follow the same order than presented above and;

- The energetic content is comprised between 10 and $30 \%$ of fluctuation energy.

For the three first cases (C4, C10 and C11), two parameters among four are either high or small. For the last case (C12), only one parameter is small and three are high. In Table 5, the influence of the current density is taken into account by grouping all the conditions that have a low current density (J).

What is remarkable is when the current density is low compared to its nominal value, at least two other parameters must be "small" too so that it is not considered as a faulty state. If three parameters are small including the current density, the $\mathrm{SoH}$ is normal whereas if only two parameters are small, including J, the result of the $\mathrm{SoH}$ gives a faulty state.

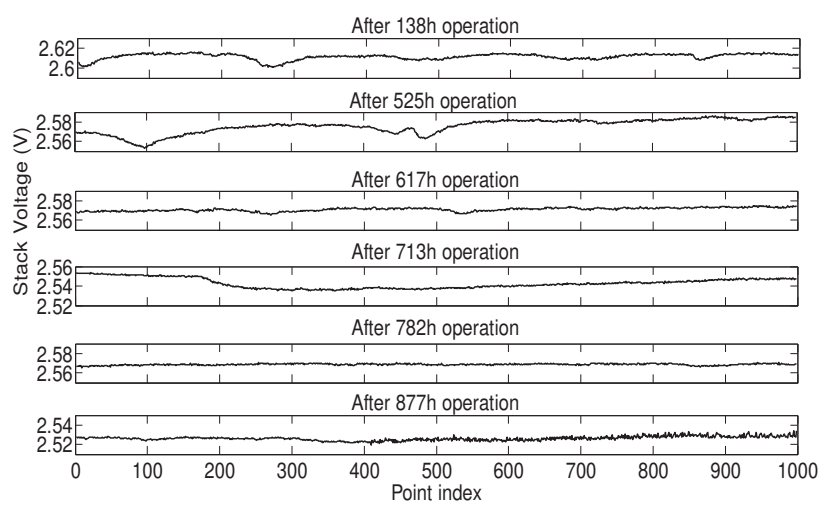

Fig. 8 - 3-cell stack voltage evolution depending on the ageing time at $\mathrm{T}=770{ }^{\circ} \mathrm{C}$ and $\mathrm{I}=6 \mathrm{~A}$.

Table 3 - 3-cell stack specifications.

\begin{tabular}{ll} 
Parameter & \multicolumn{1}{c}{ Value } \\
\hline Number of cells & 3 \\
Fuel (mol\%) & $\mathrm{H}_{2}(16)-\mathrm{N}_{2}(51.2)-\mathrm{CO}(14.6)-\mathrm{CO}_{2}$ \\
& $(9)-\mathrm{H}_{2} \mathrm{O}(9.2)$ \\
Active area per cell & $50 \mathrm{~cm}^{2}$ \\
Nominal temperature & $770^{\circ} \mathrm{C}$ \\
Maximal temperature & $850^{\circ} \mathrm{C}$ \\
Nominal current density & $0.3 \mathrm{~A} / \mathrm{cm}^{2}$ \\
$\mathrm{H}_{2}$ utilization & 0.6 \\
Air utilization & 0.25 \\
\hline
\end{tabular}




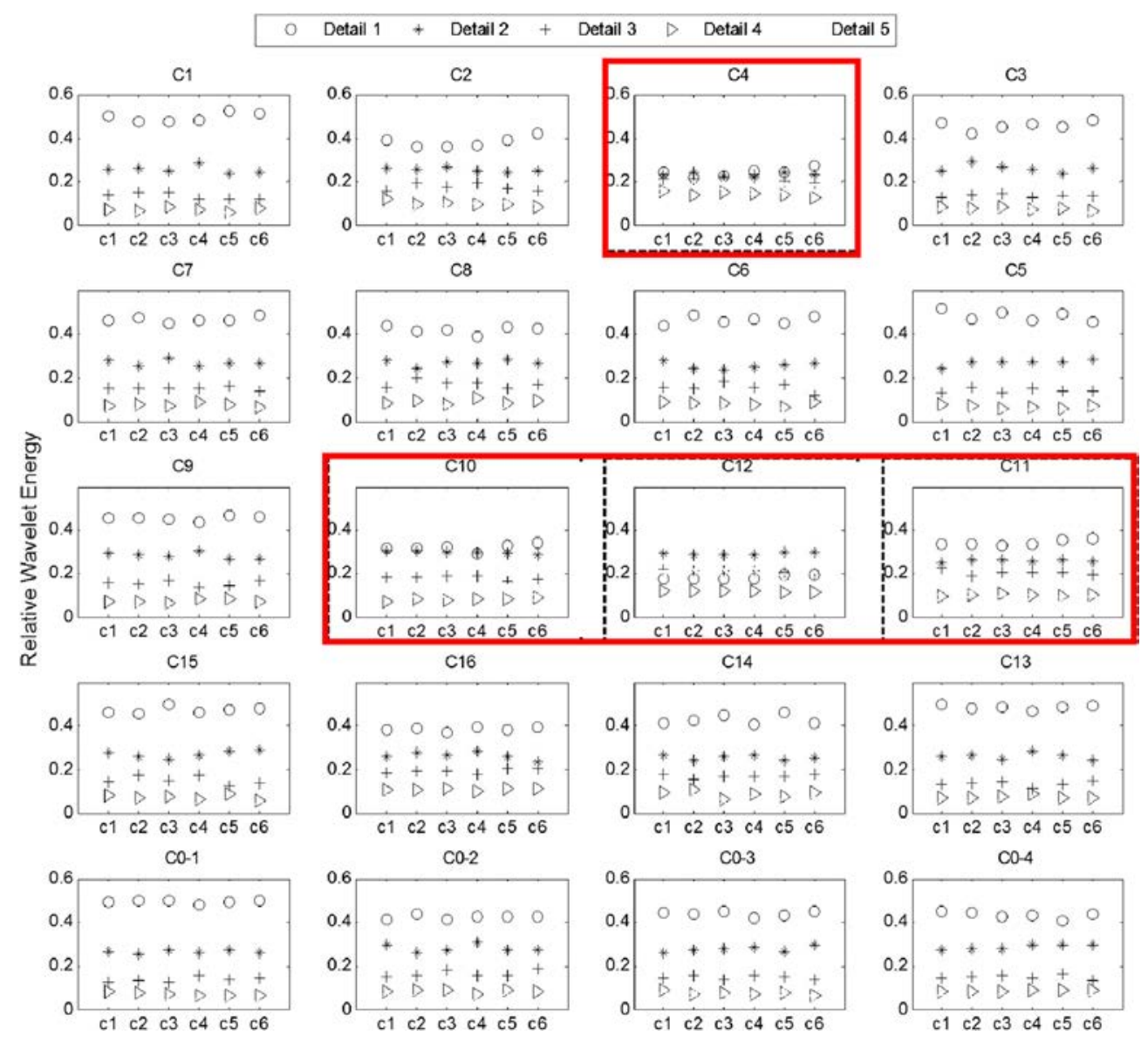

Fig. 9 - RWE of a 6-cell SOFC voltage linked to different operating conditions.

Table 4 - Faulty operating conditions of the SOFC.

\begin{tabular}{lllll} 
Conditions & \multicolumn{1}{c}{$\mathrm{T}$} & \multicolumn{1}{c}{$\mathrm{J}$} & \multicolumn{1}{c}{$\mathrm{FU}$} & $\mathrm{AU}$ \\
\hline $\mathrm{C} 0-\sharp$ (nominal) & $760{ }^{\circ} \mathrm{C}$ & $0.3 \mathrm{~A} / \mathrm{cm}^{2}$ & 0.5 & 0.4 \\
4 & Small & Small & High & High \\
10 & High & Small & Small & High \\
11 & High & Small & High & Small \\
12 & High & Small & High & High \\
\hline
\end{tabular}

As a conclusion, C4 and C12 should be considered as critical operating conditions which are harmful to the SOFC SoH. Moreover, C10 and C11 represent commonly a hightemperature situation, especially in C11 where both $\mathrm{T}$ and FU are at their highest level, which is a risk of accelerating the FC degradation. In C10, the air utilization is high and the current density is low, which implies that the air flow rate is at a very low level. This condition is harmful for the stack in a large-scale system where the air flow should be kept at a relatively higher level than needed in order to remove the produced heat and water in the stack. Therefore, both of these two conditions are undesired [43].

\section{b. The TWP indicators}

On Fig. 10, the TWP values are shown depending on the 20 operating conditions tested on the 6 -cell stack. The
Table 5 - Operating conditions with a small current density J.

\begin{tabular}{llllll} 
Conditions & T & \multicolumn{1}{c}{ J } & FU & AU & SoH \\
\hline 1 & Small & Small & Small & Small & Normal \\
2 & Small & Small & Small & High & Normal \\
3 & Small & Small & High & Small & Normal \\
4 & Small & Small & High & High & Fault \\
9 & High & Small & Small & Small & Normal \\
10 & High & Small & Small & High & Fault \\
11 & High & Small & High & Small & Fault \\
12 & High & Small & High & High & Fault \\
\hline
\end{tabular}

The bold text is to specify that the current density $\mathrm{J}$ is in all cases "Small" and that implies sometimes a faulty state-of-health (SoH).

entropy of each cell is analyzed in order to see the different behaviour and the distribution all along the stack. The different conditions $\mathrm{C} \sharp$ are set in the same order as previously, with the four nominal states at the end of the graph. The dash line represents the same value for each cell that is equal to 2, called criterion line, in order to make the extreme values of TWP more visible. Again, four harmful conditions reach a maximal TWP value of about 2.3 that gives $\mathrm{C} 4-\mathrm{C} 10-\mathrm{C} 11$ and $\mathrm{C} 12$ whatever the cell number. 


\section{c. The RWP indicators}

The RWP aims at normalizing the entropy indicator by choosing a reference signal. In this paper, all the abnormal conditions are evaluated and compared with the nominal condition C0-\#. Thus, the indicator is centered at zero. In the same way as previously, four critical operating conditions are visible (i.e. C4, C10, C11 and C12). Fig. 11 illustrates that the RWP is useful to validate the fault diagnosis. By comparing the results of analysis, 2 threshold values (i.e. 0.05 and 0.5 ) could be yielded to divide the RWP values into 3 clusters [43], each of them indicating the state of health of the SOFC. That gives:

- Normal operation for the interval [0, 0.05];

- Abnormal operation for [0.05, 0.5] and;

- Stack broken for [0.5].

\section{3-cell stack diagnosis results}

The same fault diagnosis procedure is applied with the 3-cell stack. Some steady state voltage signals are recorded during about $1677 \mathrm{~h}$ and 6 polarization curves that aim at showing the degradation over time of the fuel cell were performed. The fault diagnosis algorithm is here used as an indicator of the ageing degradation of the system: the RWP values for each characterization time is calculated and illustrated on Fig. 12. The first signal (at $138 \mathrm{~h}$ ) is considered as the reference for the normalization way. The RWP value follows an increasing trend, which is similar to the degrading process of the stack, visible on the different polarization curves. Accordingly, the RWP could be considered as an effective indicator of the state of health of the SOFC stack.

\section{Conclusion}

The signal-based method used in this work aimed at faults diagnostics of an SOFC stack. It has been also used to provide an indication on the ageing of a stack during a long-term test. The fault diagnosis uses the wavelet transform to divide the initial signal (voltage) into high frequency and low frequency parts. A focus is given to the fluctuation of the high frequency part by studying each detail $D_{j}$ (where $j$ is the decomposition level). Afterwards, three indicators were extracted from the signals and studied in order to validate their ability to detect the SoH of the SOFC system: RWE, TWP and RWP. In this paper, two kinds of dataset were analyzed: on the one hand, a 6 -cell stack is used to test 16 different operating conditions by making several combinations of four parameters (i.e. temperature, current density, fuel utilization and air utilization) around nominal values. Whereas on the other hand, a longterm test is performed on a shorter stack. In this case, the natural degradation of the fuel cell (called ageing) is studied and determined thanks to energy and entropy-based indicators. For the first database, the energy distribution (RWE) contained in the details $D_{j}$ is observed on 17 different operating conditions containing 4 abnormal/faulty conditions. Their energy distribution and their maximal magnitude are very separated when confronted with the other conditions and especially nominal modes. The TWP is also calculated and allowed distinguishing the same 4 degrading modes from the healthy ones. However, this parameter is less discriminative than the RWP, because it only isolates two critical conditions among the 4 selected. For the second dataset, the validity of the three parameters for SOFC diagnostics is improved by detecting the of the SOFC stack when performing ageing (longterm) tests. On the second test, the ageing of the fuel cell is taken into account by the signal-based method. The RWP values fit with the degradation observed on the polarization curves. In the presented methodology, the RWE is very useful to see the fluctuating behaviour of the voltage signal details. It is helpful to understand the variations existing on the high frequency part of the measured voltage signal when a fault occurs on the system. The distribution and the maximal

Cell 1

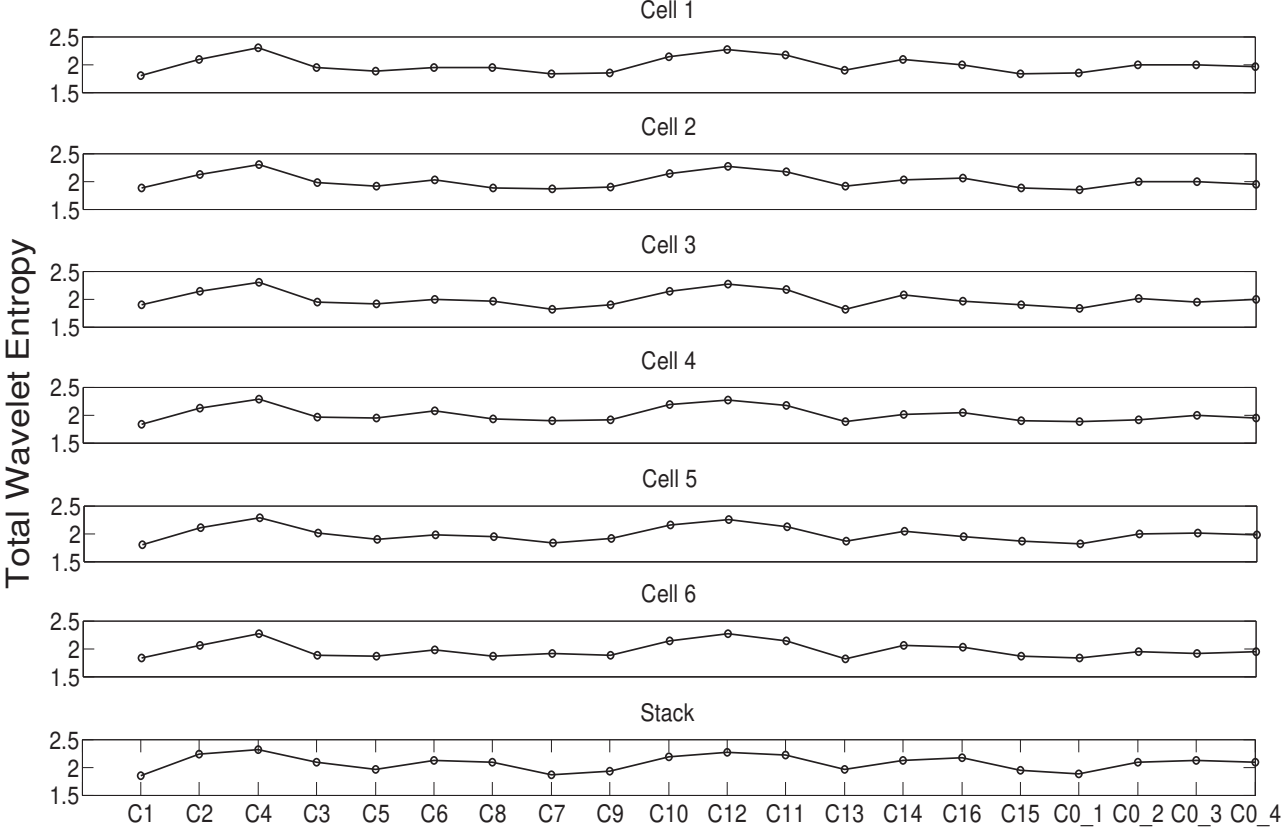

Fig. 10 - TWP plots by individual cell according to 20 operating conditions. 
Cell 1

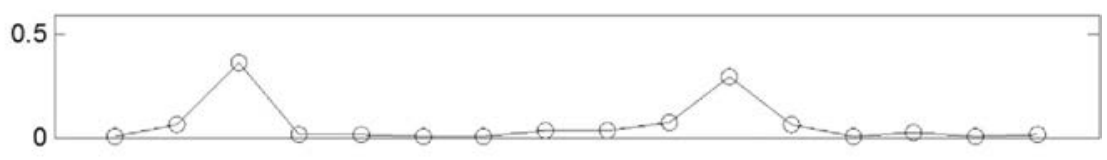

Cell 2

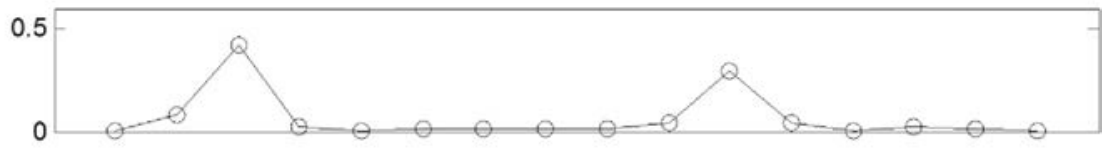

Cell 3

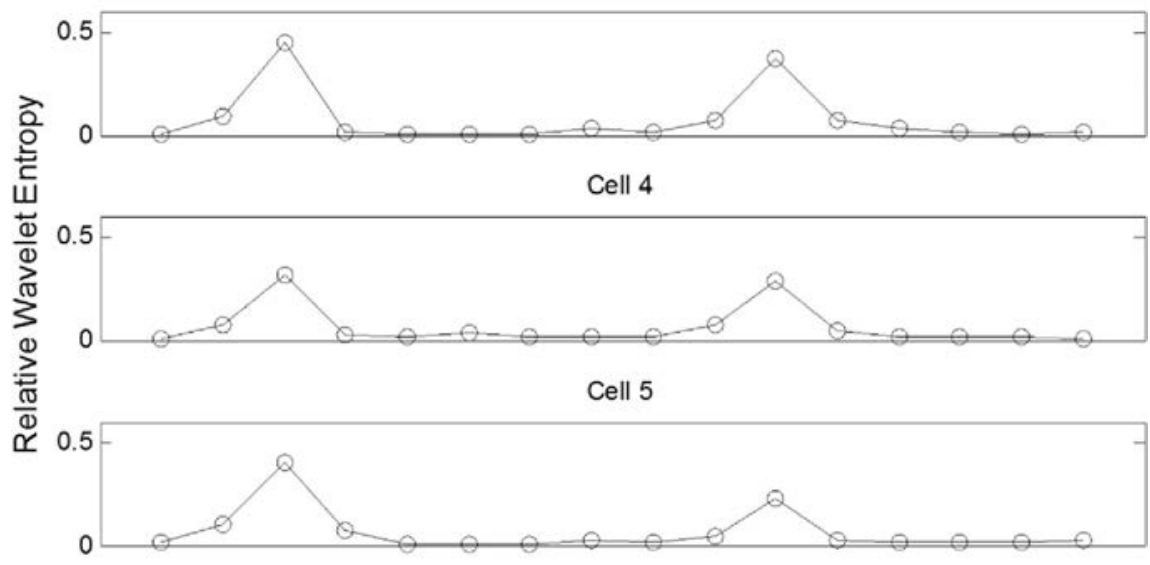

Cell 6

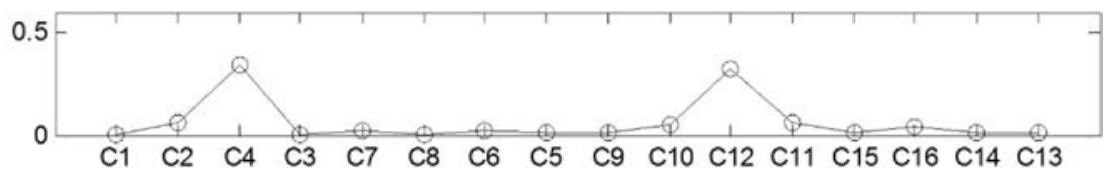

Fig. 11 - RWP plots by individual cell according to 16 operating conditions.

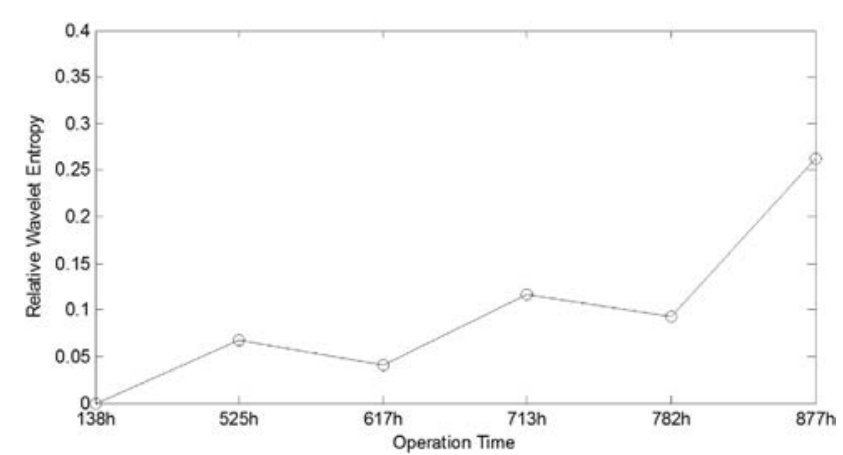

Fig. 12 - RWP trend according to the ageing time.

magnitude of the energy contained in a signal are very discriminating. Finally, this indicator aims at determining the significant frequency band relevant to the fault. As for TWP, it is able to detect a deviation from the nominal conditions. Although it is not as effective as RWP for fault indication, this indicator is successful for tracking the variation of the system operation. Finally, the RWP is the most effective indicator for the $\mathrm{SoH}$ of a SOFC, by allowing a detection of the fuel cell damages and also by well-fitting an ageing phenomenon. Consequently, the analysis of the three parameters (RWE, TWP and RWP) indicates the operating conditions and the state of health of the SOFC quite rapidly and with no additional sensor. It is important to notice that the choice of the decomposition level must be as closest as possible to the significant frequency band that is relevant to the fault detection and isolation.

\section{Acknowledgements}

The authors acknowledge the project GENIUS (funded by the European Community 7th Framework Programme FP7/20072013 for the Fuel Cells and Hydrogen Joint Technology Initiative under grant agreement $n^{\circ} 245128$ ) and also the Labex ACTION, ANR-11-LABX-01-01, for financially supporting these works and offering the possibility of using their data.

\section{R E F E R E N C E S}

[1] Wang K, Hissel D, Péra MC, Steiner N, Marra D, Sorrentino M, et al. A review on solid oxide fuel cell models. Int J Hydrogen Energy 2011;36:7212-28.

[2] Voldsund M, Jordal K, Anarntharaman R. Hydrogen production with $\mathrm{CO}_{2}$ capture. Int J Hydrogen Energy 2016;41(9):4969-92.

[3] Agency IE. Hydrogen production and storage. 2006. Tech rep. International Energy Agency. 
[4] Eveloy V. Numerical analysis of an internal methane reforming solid oxide fuel cell with fuel recycling. Appl Energy 2012;93:107-15.

[5] Strakey JP, Williams M, Surdoval WA, Singhal SC. U. S. DOE solid oxide fuel cell program. In: Proceedings of sixth European solid oxide fuel cell forum, vol. 1; 2004. p. 48-59. June 28-July 2, 2004, Lucerne, Switzerland.

[6] Klotz D, Leonide A, Weber A, Ivers-Tiffée E. Electrochemical model for SOFC and SOEC mode predicting performance and efficiency. Int J Hydrogen Energy 2014;39(35):20844-9.

[7] Singhal SC. Advances in solid oxide fuel cell technology. Solid State Ionics 2000;135:305-13.

[8] EG\&G Technical services, Inc. Fuel cell handbook. 6th ed. U.S. Department of Energy; November 2002.

[9] Verma JK, Verma A, Ghoshal AK. Performance analysis of solid oxide fuel cell using reformed fuel. Int J Hydrogen Energy 2013;38(22):9511-8.

[10] Sammes NM, Du Y, Bove R. Design and fabrication of a 100W anode supported micro-tubular SOFC stack. J Power Sources 2005;145:428-34.

[11] Chinda P, Brault P. The hybrid solid oxide fuel cell (SOFC) and gas turbine (GT) systems steady state modeling. Int J Hydrogen Energy 2012;37(11):9237-48.

[12] Alenazey F, Alyousef Y, Brancaccio E, Montinaro D. Parameters affecting $\mathrm{CO}_{2}$ production in a planar anode supported SOFC based system. Int J Hydrogen Energy 2015;40(1):642-51.

[13] Unal FA, Mat MD, Demir I, Kaplan Y, Veziroglu N. Application of a coating mixture for solid oxide fuel cell interconnects. Int J Hydrogen Energy 2015;40(24):7689-93.

[14] Fang Q, Blum L, Peters R, Peksen M, Batfalsky P, Stolten D. SOFC stack performance under high fuel utilization. Int $J$ Hydrogen Energy 2015;40(2):1128-36.

[15] Lebreton M, Delanoue B, Baron E, Ricoul F, Kerihuel A, Subrenat A, et al. Effects of carbon monoxide, carbon dioxide, and methane on nickel/yttria-stabilized zirconiabased solid oxide fuel cells performance for direct coupling with a gasifier. Int J Hydrogen Energy 2015;40(32):10231-41.

[16] LinJ, Trabold TA, Walluk MR, Smith DF. Bio-fuel reformation for solid oxide fuel cell applications. Part 1: fuel vaporization and reactant mixing. Int J Hydrogen Energy 2013;38(27):12024-34.

[17] Fuel Cell Today. The fuel cell today industry, Review. 2011.

[18] NETL. Fuel cell handbook. University Press of the Pacific; 2005.

[19] Eveloy V, Karunkeyoon W, Rodgers P, Al Alili A. Energy, exergy and economic analysis of an integrated solid oxide fuel cell - gas turbine - organic Rankine power generation system. Int J Hydrogen Energy 2016;41(31):13843-58. http:// dx.doi.org/10.1016/j.ijhydene.2016.01.146. Available online 23 February 2016.

[20] Birggersson KE, Balaya P, Chou SK, Yan J. Energy solutions for a sustainable world. Appl Energy 2012;90:1-2.

[21] Barelli L, Bidini G, Gallorini F, Ottaviano A. An energeticexergetic comparison between PEMFC and SOFC-based microCHP systems. Int J Hydrogen Energy 2011;36(4):3206-14.

[22] Lim TH, Song RH, Shin DR, Yang JI, Jung H, Vinke IC, et al. Operating characteristics of a $5 \mathrm{~kW}$ class anode-supported planar SOFC stack for a fuel cell/gas turbine hybrid system. Int J Hydrogen Energy 2008;33(3):1076-83.

[23] Tu H, Stimming U. Advances, aging mechanisms and lifetime in solid-oxide fuel cells. J Power Sources 2004;127:284-93.

[24] Cadet C, Jemei S, Druart F, Hissel D. Diagnosis tools for PEMFCs: from conception to implementation. Int J Hydrogen Energy 2014;39:10613-26.

[25] Petrone R, Zheng Z, Hissel D, Pra MC, Pianese C, Sorrentino M, et al. A review on model-based diagnosis methodologies for PEMFCs. Int J Hydrogen Energy 2013;38:7077-91.

[26] Hua J, Li J, Ouyang M, Lu L, Xu L. Proton exchange membrane fuel cell system diagnosis based on the multivariate statistical method. Int J Hydrogen Energy 2011;36:9896-905.
[27] Lechartier E, Laffly E, Péra MC, Gouriveau R, Hissel D, Zerhouni N. Proton exchange membrane fuel cell behavioral model suitable for prognostics. Int J Hydrogen Energy 2015;40(26):8384-97.

[28] Zheng Z, Petrone R, Péra MC, Hissel D, Béchérif M, Pianese C, et al. A review on non-model based diagnosis methodologies for PEM fuel cell stacks and systems. Int J Hydrogen Energy 2013;38:8914-26.

[29] Giurgea S, Tirnova R, Hissel D, Outbib R. An analysis of fluidic voltage statistical correlation for a diagnosis of PEM fuel cell flooding. Int J Hydrogen Energy 2013;38:4689-96.

[30] Yousfi-Steiner N, Hissel D, Mooteguy P, Candusso D. Nonintrusive diagnosis of polymer electrolyte fuel cells by wavelet packet transform. Int J Hydrogen Energy 2011;36:740-6.

[31] Barelli L, Barluzzi E, Bidini G. Diagnosis methodology and technique for solid oxide fuel cells: a review. Int J Hydrogen Energy 2013;38(12):5060-74.

[32] Andersson M, Yuan J, Sundén B. Review on modeling development for multi-scale chemical reactions coupled transported phenomena in SOFCs. Appl Energy 2010;87:1461-76.

[33] Zabihian Fung A. A review on modeling of hybrid solid oxide fuel cell systems. Int J Eng 2009;3(2):85-119.

[34] Pohjoranta A, Halinen M, Pennanen J, Kiviaho J. Solid oxide fuel cell stack temperature estimation with data-based modeling - designed experiments and parameter identification. J Power Sources 2015;277:464-73.

[35] Ibrahim M, Wimmer G, Jemei S, Hissel D. Energy management for a fuel cell hybrid electrical vehicle. In: 40th Annual Conference of the IEEE industrial electronics society; 2014. p. 3955-61.

[36] Ibrahim M, Jemei S, Hissel D, Wimmer G. On-board energy management for a hybrid vehicle: wavelet based approach. In: Int. Scientific Conference on hybrid and electric vehicles (RHEVE); 2011. p. 1-8.

[37] Wang K, Hissel D, Péra MC, Steiner NY. Developing a generic tool for in-situ diagnosis on solid oxide fuel cell (SOFC). In: International Conference on fundamentals and developments of fuel cells (FDFC); 2010. 7pp.

[38] Yousfi Steiner N, Wang K, Péra M-C, Hissel D. Localisation d un ou plusieurs défauts dans un ensemble électrochimique. 2012. brevet d invention; demande prioritaire : FR 1262319 ; Extension de la protection N : PCT/ FR2013/053163 dépôt Novembre 2012.

[39] Mallat S. A wavelet tour of signal processing the sparse way. 3rd ed. Elsevier Academic Press; 2009. 805pp.

[40] Walker JS. A primer on wavelets and teir scientific applications. 2nd ed. Eau Claire, Wisconsin, U.S.A: University of Wisconsin; 2008 [Chapman \& Hall/CRC, Taylor \& Francis Groups, LLC].

[41] Isermann R. Fault-diagnosis systems: an introduction from fault detection to fault tolerance. Springer; 2006. 475pp.

[42] Li J, Kang YW, Cao GY, Zhu XJ, Tu HY, Li J. Nonlinear identification of a DIRSOFC stack using wavelet networks. J Power Sources 2008;179:673-82.

[43] Wang K. Ex-situ and in-situ diagnostic algorithms and methods for solid oxide fuel cell systems. PhD thesis. University of Franche-Comte; 2012. 168pp.

[44] Emre Cek M, Ozgoren M, Acar Savaci F. Continuous time wavelet entropy of auditory evoked potentials. Comput Biol Med 2010;40:90-6.

[45] Esposito A, Postiglione F, Pohjoranta A, Wang K, Pofahl S, Mocoteguy P, et al. Experimental test plan and data analysis based on the design of experiment methodology. In: Proc ASME ESFuelCell; 2012. p. 293-302. 